\title{
Article
}

http://dx.doi.org/10.11646/phytotaxa.174.5.6

\section{Lectotypification and further notes on the identity of Commelina hirsuta, an endemic Indian species of Commelinaceae}

\author{
SANTHOSH NAMPY ${ }^{1}$, SHEBA M. JOSEPH ${ }^{2} \&$ MANUDEV K.M ${ }^{1}$ \\ ${ }^{\prime}$ Department of Botany, University of Calicut, Kerala - 673 635, India \\ ${ }^{2}$ Department of Botany, St. Mary's College, Sulthan Bathery, Kerala, India \\ santhoshnampy5@gmail.com,shebamjoseph@gmail.com,manudevkmadhavan@gmail.com
}

\begin{abstract}
The identity and nomenclature of the endemic Indian species Commelina hirsuta (Wight) Beddome (Commelinaceae) has puzzled taxonomists. This was further accelerated by the publication of a new name Commelina beddomei for this species recently. In the present paper, the identity and nomenclature of Commelina hirsuta (Wight) Beddome is discussed. A lectotype is designated and additional notes on the species are provided.
\end{abstract}

Key words: Commelina hirsuta, Commelina beddomei, Commelina wightii, lectotype, India

\section{Introduction}

Commelina Linnaeus (1753: 40) is the largest genus of Commelinaceae with about 233 taxa in the world (Govaerts \& Faden, 2014). It is the second largest genus of this family in India with 25 species, of which 5 species (20\%) are endemic (Sheba et al., 2012; Nampy et al., 2013; Sheba, 2013).

In the undisturbed grassy hill slopes of southern peninsular India, usually above $1800 \mathrm{~m}$ altitude, there grows an endemic species of Commelina characterized by hairy stems and leaves, linear-lanceolate leaves, complicate spathes with purplish margins, blue flowers and one seeded capsules. This species was first described by Robert Wight (1853) under the name Heterocarpus hirsutus Wight (1853: 29). Beddome (1880) transferred this species to Commelina as C. hirsuta (Wight) Beddome (1880: 122). However, his combination remained unnoticed for a long time. In the meanwhile, Clarke (1881) also made the same combination and 'C. hirsuta (Wight) C.B. Clarke' was used by various authors in their floras (Hooker, 1892; Woodrow, 1900; Cooke, 1906; Rama Rao, 1914; Fischer, 1931; Nayar \& Sastry, 1987; Ahmedullah \& Nayar, 1987; Karthikeyan et al., 1989; Henry et al., 1989; Lakshminarasimhan \& Sharma, 1991; Sharma et al., 1996; Pullaiah, 1997; Matthew, 1999).

The name Commelina hirsuta was used earlier by various authors for different taxa (Commelina hirsuta Brown (1814: 62); Commelina hirsuta Willd. ex Link (1820:74); Commelina hirsuta Hort. ex Kunth (1843: 660); Commelina hirsuta Hochst. ex Richard (1850: 344). All these names were published either without accompanying description (nom. nud.) or as synonyms (pro syn.) and are hence invalid (McNiell et al., 2012). After studying relevant literature and personal discussion with Dr. Kanchi N. Gandhi (Senior Nomenclatural Registrar, Harvard University), we conclude that Commelina hirsuta (Wight) Beddome (1880: 122) is the correct name for the endemic Indian species described by Robert Wight (1853) under the name Heterocarpus hirsutus. Since the name Commelina hirsuta (Wight) Beddome is valid and legitimate, the name Commelina beddomei published by Nandikar and Gurav (Nandikar \& Gurav, 2014) is superfluous and illegitimate.

Wight (1853) described this species from Nilgiris, India. While searching for Wight's specimens in different herbaria it was found that there are three sheets at $\mathrm{K}$, all apparently part of a single collection. There is one sheet at $\mathrm{MH}$ kept among Wight's collections, but this lacks any label or name in Wight's handwriting. According to Noltie (2005), there are no possible types at $\mathrm{E}$. Of the three sheets at K, one lacks anything in Wight's handwriting, the second bears a description by Wight and on the third sheet a field label annotated 'Avalangy, October 1852'. This third sheet contains five specimens which are marked here as A-E. Among them, specimen ' $\mathrm{A}$ ' is a perfect match for the description is designated here as the lectotype. 
Flowering \& Fruiting:--July-November.

Ecology and Distribution:-Endemic to India, among grasses on mountainous slopes, usually above $1800 \mathrm{~m}$ altitude.

Specimens examined:- INDIA. Andhra Pradesh: Karimnagar district, Aklaspur, 26 July 1964, G.V. Subba Rao 20213 (MH). Kerala: Palaghat district, Meenbani, on the way to Koodam, Silent Valley Buffer Zone, 31 October 2013, Manudev \& Santhosh Nampy 135129; On the way to Ankinda from Meenbani, Silent Valley Buffer Zone, 01 November 2013, Manudev \& Santhosh Nampy 135148 (CALI). Tamil Nadu: Dindigal district, Kodaikanal, 14 July 1898, s.coll. 72869; Ibid., 1872, Bowha s.n.; Ibid., May 1937, s.coll. s.n. (RHT); Kodaikanal-Kukal Pulneys, 17 July 1920, s.coll. 16519 (MH); Konalar, 06 August 1984, K.M. Matthew 40634; Mahil Kundiam, 11 September 1986, K.M. Matthew 46835; Mannavanur Sheep Farm, 28 August 1987, K.M. Matthew 50474 (RHT); Pulney, Curdon Valley, 23 June 1898, A.G. Bourne 1233 (CAL); Vembadi Peak, 07 August 1984, K.M. Matthew 40710; Ibid., 04 July 1987, K.M. Matthew 49849; Ibid., 27 August 1987, K.M. Matthew \& N. Rajendran 50413; La providence, Marian Shola, 06 October 1966, K.M. Matthew 7452, 7453 (RHT). Nilgiri district, Dodabetta, August 1883, s.coll. 52246; Mukurti, 14 July 1970, J.L. Ellis 34670 (MH); Naduvattom, 18 August 1878, G. King s.n. (DD, CAL); Ibid., October 1884, Gamble 14868, 14879 (DD); Pandian Dam site, 28 October 1972, J.L. Ellis 43427; Pykara, 12 September 1930 , V. Narayanaswami 4753; Ibid., 31 August 1970, B.D. Sharma 35965 (MH); Ootty, 08 August 1878, G. King s.n. (DD); Ibid., 12 August 1878, G. King s.n. (CAL); Ibid, July 1883, s.coll. s.n. (MH).

Notes:-The flower colour is described differently by various authors. Wight (1853) described the genus Heterocarpus (=Commelina) as yellow-flowered and included two species namely, H. hirsutus (= Commelina hirsuta) and H. glaber (=Commelina wightii), specifically mentioning the colour as yellow in the latter but not in the former. Fischer (1931) described the flower as yellow, drying deep-blue, Barnes (1946) as deep turquoise blue and Matthew (1999) as blue. During the present investigation, we have collected plants with only blue flowers.

According to Fyson (1919), the yellow flowered species of Wight (1853) Heterocarpus glaber (=Commelina wightii Rao 1962:168) and H. hirsutus (=Commelina hirsuta) produce orange flowers on the lower slopes and blue flowers on the higher and assumed them as two varieties- a glabrous and a hairy of one species. However, we find that they are quite distinct and $C$. hirsuta can be separated from $C$. wightii in having a definite base, thick roots, linearlanceolate leaves, hairy ovary and blue flowers. Though both species produce 1-seeded capsules, the seed is produced in the dorsal locule which is attached with the capsule wall in the former and in a ventral locule in the latter which is free from the capsule wall.

\section{Acknowledgements}

We are thankful to the Head, Dept. of Botany and Principal, St. Joseph's College, Kozhikode for facilities; Dr. Kanchi N. Gandhi (Harvard University) for nomenclatural discussions; Mr. K.P. Vimal, Research Fellow, Calicut University for assisting collections and Department of Forests, Government of Kerala for permission. SMJ is thankful to the University Grants Commission, New Delhi for Teacher Fellowship and MKM for Senior Research Fellowship.

\section{References}

Ahmedullah, M. \& Nayar, M.P. (1987) Endemic plants of Indian region. Vol. 1. Botanical Survey of India, Kolkata. 261 pp.

Barnes, E. (1946) Some observations on South Indian Commelinaceae: two new species of Commelina from South India. Journal of Bombay Natural History Society 46: 70-89.

Beddome, R.H. (1880) Chapter VI- Flora. In: H.B. Grigg (Ed.) A manual of the Nílagiri district in the Madras Presidency. E.Keys, The government press, Madras. pp. 98-132.

Brown, R. (1814) List of new and rare plants collected in Abyssinia during the years 1805 and 1810, arranged according to the Linnaean system. In: Salt, H. (Ed.) A voyage to Abbysinia. App. IV. F.C. \& J. Rivington, London. pp. 62-65.

Clarke, C.B. (1881) Commelinaceae. In: Candolle, A.L.P. de \& Candolle, A.C. de (Ed.) Monographiae Phanerogamarum. Vol. 3. G. Masson, Paris. pp. 113-324.

Cooke, T. (1906) Flora of the Presidency of Bombay. 2: 779-797. Taylor \& Francis, London.

Fischer, C.E.C. (1931) Commelinaceae. In: J.S. Gamble (Eds.) Flora of Presidency of Madras. Vol. 3. Adlard \& Son, Ltd., London. pp. $1533-1552$

Fyson, P.F. (1919) Short notes on distribution, etc. Journal of Indian Botany 1: 125-127. 
Govaerts, R. \& Faden, R.B. (2014) World Checklist of Commelinaceae. Facilitated by the Royal Botanic Gardens, Kew. Published on the Internet; http://apps.kew.org/wcsp/ accessed 21 March 2014.

Henry, A.N., Chitra, V. \& Balakrishnan, N.P. (1989) Flora of Tamil Nadu Analysis. Vol.3. Botanical Survey of India, Kolkata.

Hooker, J.D. (1892) Flora of British India. Vol. 6. L. Reev \& Co., London, pp. 366-390.

Karthikeyan, S., Jain, S.K., Nayar, M.P. \& Sanjappa, M. (1989) Florae Indicae Enumeratio: Monocotyledonae. Botanical Survey of India. Kolkata, pp. 24-26.

Kunth, C.S. (1843) Enumeratio Plantarum. Vol. 4. Stuttgart \& Tubingen, pp. 34-117.

Lakshminarasimhan, P. \& Sharma, B.D. (1991) Flora of Nasik district, Maharashtra. Botanical Survey of India, Kolkata.

Linnaeus, C. (1753) Species Plantarum. Holmiae, Impensis Laurentii Salvii, pp. 40-42.

Link, H.F. (1820) Der Botanische Garten bei Berlin und die Willdenowsche Kraautersammlung. Jahrbücher der Gewächskunde. Berlin and Leipzig 1(3): 74.

Matthew, K.M. (1999) The Flora of the Palni Hills Vol.3. The Rapinat Herbarium, Tiruchirappalli, pp. 1339-1343.

McNeill, J., Barrie, F.R., Buck, W.R., Demoulin, V., Greuter, W., Hawksworth, D.L., Herendeen, P.S., Knapp, S., Marhold, K., Prado, J., Prud'homme van Reine, W.F., Smith, G.F., Wiersema, J.H. \& Turland, N.J. (2012) International Code of Nomenclature for algae, fungi, and plants (Melbourne Code). Regnum Vegetabile 154. Koeltz Scientific Books.

Nampy, S., Sheba, M.J. \& Manudev, K.M. (2013) The genus Commelina L. (Commelinaceae ) in Andaman \& Nicobar Islands, India with one new species and three species records. Phytotaxa 87(2): 19-29.

Nandikar, M.D. \& Gurav, R.V. (2014) Commelina beddomei (Commelinaceae), a new name for endemic Beddome's Commelina hirsuta from Western Ghats of India. Plant Sciences Feed 4(1): 1-5.

Nayar, M.P. \& Sastry, A.R.K. (1987) Red data Book of Indian plants. Vol.1. Botanical Survey of India, Kolkata, 367pp.

Noltie, H.J. (2005) The Botany of Robert Wight. ARG. Gantner, Verlag. 579 pp.

Pullaiah, T. (1997) Flora of Andhra Pradesh. Vol. 3. Scientific Publishers, Jodhpur.

Rama Rao. M. (1914) Flowering Plants of Travancore. Government Press, Thiruvananthapuram. 200 pp.

Rao, R.S. \& Kammathy, R.V. (1962) Notes on Indian Commelinaceae V. Bulletin of Botanical Survey of India 3: 168.

Richard, A. (1850) Tentamen florae Abyssinicae: seu Enumeratio plantarum hucusque in plerisque Abyssiniae provinciis detectarum. V. 2. Arthus Bertrand, Paris, pp. 340-345.

Sharma, B.D., Karthikeyan, S. \& Singh, N.P. (1996) Flora of Maharashtra (Monocotyledons). Botanical Survey of India, Kolkata, pp. $147-183$

Sheba, M.J. (2013) Taxonomic revision of the genus Commelina L. (Commelinaceae) in India. Ph.D. thesis, University of Calicut, 240 pp.

Sheba, M.J., Anna Ancy, A.A. \& Nampy, S. (2012) Commelina clavatoides (Commelinaceae), a new species from Kerala, India. Journal of Botanic Research Institute of Texas 6: 119-122.

Wight, R. (1853) Icones Plantarum Indiae Orientalis or Figures of Indian Plants. Vol. 6. Messrs Franck \& Co., Madras, pp. $2065-2066$.

Woodrow, G.M. (1900) The flora of Western India- Part VII. Journal of Bombay Natural History Society 12: 515-526. 